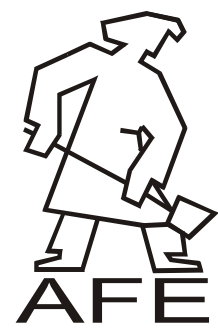

\title{
Effect of Magnesium Oxide Nanoparticles on Water Glass Structure
}

\author{
A. Bobrowski*, A. Kmita, M. Starowicz, B. Stypuła, B. Hutera \\ AGH University of Science and Technology, Faculty of Foundry Engineering, Cracow, Poland \\ *Contact for correspondence: e-mail: arturb@agh.edu.pl
}

Received 16.04.2012; accepted in revised form 02.07.2012

\begin{abstract}
An attempt has been made to determine the effect of an addition of colloidal suspensions of the nanoparticles of magnesium oxide on the structure of water glass, which is a binder for moulding and core sands. Nanoparticles of magnesium oxide $\mathrm{MgO}$ in propanol and ethanol were introduced in the same mass content (5wt.\%) and structural changes were determined by measurement of the FT-IR absorption spectra.
\end{abstract}

Keywords: Modification, Water glass, Nanoparticles of $\mathrm{MgO}$

\section{Introduction}

Water glass as a binder was used for the first time in 1947 (Czechoslovak Patent No. 81 931). It is cheap, readily available and nontoxic. However, an evident drawback of foundry sands with water glass is their brittleness, poor knocking out properties and low degree of reclamability. At the same time, the potentials of water glass as a binder for foundry sand moulds and cores are not fully utilised.

In terms of technology, the following requirements should be satisfied: ensuring optimal conditions for the core and mould hardening, ensuring the required level of mechanical and physicochemical properties (strength, hygroscopicity, brittleness, etc.) and the lowest possible residual strength of moulds and cores in a wide range of temperatures $\left(300-1200^{\circ} \mathrm{C}\right)$, which will improve the sand knocking out properties and, last but not least, the moulding and core sand reclamability [1].

Studies carried out so far have indicated that the most effective improvement in the quality of sands with water glass is obtained through modification of the binder. So far, as modifiers, the multimolecular components have been used, differing in the degree of polymerisation, in molecular mass, and in the type and number of functional groups. These materials are, e.g., polyphosphates and polyacrylamides.

For several years now, a rapid development has occurred in the new group of materials known as nanoparticles [2-5]. These are, among others, the nanoparticles of ceramic materials (e.g. $\mathrm{SiO}_{2}, \mathrm{Al}_{2} \mathrm{O}_{3}, \mathrm{CaSiO}_{3}, \mathrm{MgO}$, etc. [3-8]). Operating in chemical or physico-chemical mode, nanoparticles may alter the original properties of binder. Most studies carried out so far on the modification of water glass have been focused on the use of organic compounds. Only few results reported in the literature suggest a positive impact of micro-and nanoparticles of $\mathrm{MgO}$ and $\mathrm{Cr}_{2} \mathrm{O}_{3}$ on the residual strength, which is associated with an improvement of the knocking out properties [6,7]. Additionally, all these studies are limited to investigations of the modifier impact (micro- and nanoparticles) on binder properties and are of a qualitative character. Studies undertaken recently are of a much broader range, including modifier impact on the structure and properties of water glass $[8,14]$, but the relationship between composition, structure and properties is still poorly understood.

In this paper, an attempt was made to modify water glass with a colloidal suspension of nanoparticles of magnesium oxide $(\mathrm{MgO})$ in a variety of alcohols (ethanol, propanol), with constant content of the modifier in binder (5 wt $\%)$, and determine the 
effect of the addition of magnesium nanoparticles in different solvents on the structure and hardening behaviour of water glass.

\section{Experimental}

\subsection{Test materials and methods}

Binder modification was carried out on water glass:

- $\quad$ grade $\mathrm{R}, 145$ " characterised by the modulus $\mathrm{M}=2.5$ and the density $\mathrm{d}^{20}=1470 \mathrm{~kg} / \mathrm{m}^{3}$.

Water glass modifiers were:

- colloidal suspensions of $\mathrm{ZnO}$ nanoparticles of the size comprised in a range of $<100-500 \mathrm{~nm}>$ in ethanol or propanol; the concentration of the suspensions was $0.3 \mathrm{M}$.

The modification of water glass was obtained introducing 5 wt. \% of an alcohol suspension of the $\mathrm{MgO}$ nanoparticles and homogenising the mixture next.

To determine the type of interactions taking place in a bindermodifier system, an analysis was performed by FT-IR spectroscopy on samples of fresh binder and binder hardened for $24 \mathrm{~h}$ in air. The analysis was performed using a Digilab Excalibur FTSMX spectrometer with a Hatra attachment.

\section{Results and discussion}

Figure 1 illustrates the FT-IR absorption spectra of the investigated water glass (fresh and after hardening).

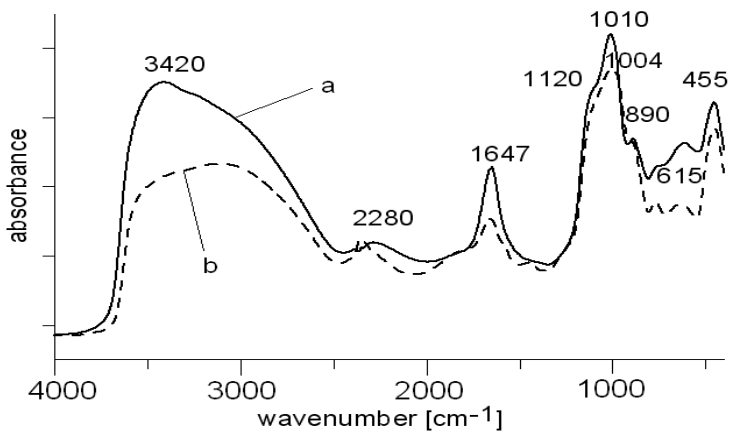

Fig. 1. FT-IR absorption spectra of the fresh water glass (a) and water glass after $24 \mathrm{~h}$ hardening (b)

The experimental determination of the structure of silicate glasses is usually done in terms of the anion structure, which is represented by $\mathrm{Q}^{\mathrm{n}}$ species (Figs. 2, )[13].

In silica glasses, the basic structural unit is tetrahedral, where $\mathrm{Si}$ is in 4-fold coordination by oxygen. The Si-centred tetrahedral structural species are designated as $\mathrm{Q}^{\mathrm{n}}$, where $\mathrm{Q}$ refers to silicon atoms and $n$ denotes the number of bridging oxygen (BO) in a structural unit. The $\mathrm{Q}^{0}$ species are isolated $\left(\left[\mathrm{SiO}_{4}\right]^{-4}\right)$ - monomers; the $\mathrm{Q}^{1}$ species are $\left(\left[\mathrm{Si}_{2} \mathrm{O}_{7}\right]^{-6}\right)$ - dimers; in the $\mathrm{Q}^{2}$ species, the structural unit is $\left(\left[\mathrm{SiO}_{3}\right]^{-2}\right)$ - chains; the $\mathrm{Q}^{3}$ structural species form $\left(\left[\mathrm{Si}_{2} \mathrm{O}_{5}\right]^{-2}\right)$ - sheets; the $\mathrm{Q}^{4}$ structural species are arranged in tetrahedral configurations as $\mathrm{SiO}_{2}$.

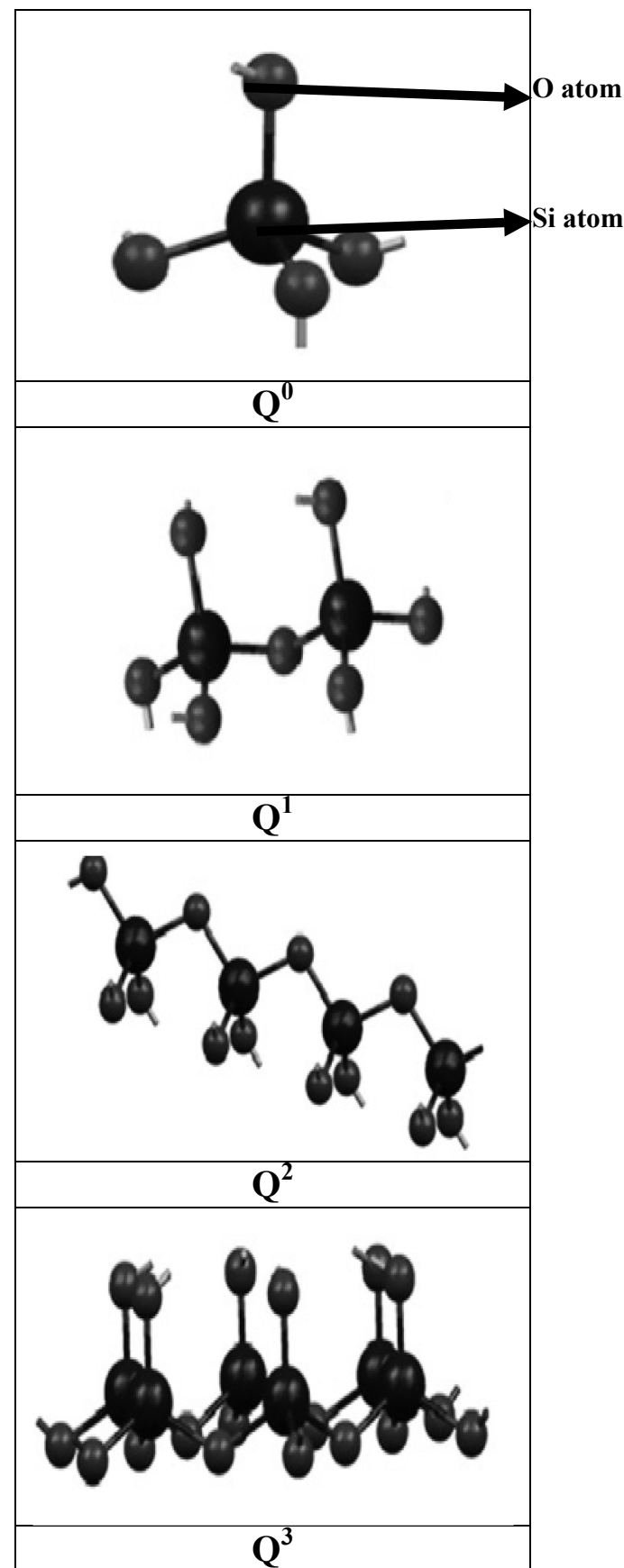

Fig. 2. The structure of silicate glasses $\left(\mathrm{Q}^{\mathrm{n}}\right)$ [13]

The FTIR absorption spectra of the investigated water glass $(\mathrm{M}=2,5)$, fresh and hardened (Fig.1), can be divided into two groups: the first one comprises the main sharp distinctive and characteristic absorption bands ranging from $400-1400 \mathrm{~cm}^{-1}$, which are due to vibrations of the main silicate network group with different bonding arrangements, and the second part from 1400 to $4000 \mathrm{~cm}^{-1}$ obviously consists of vibrations due to water, hydroxyl, $\mathrm{SiOH}$ or similar groups. 
It can be observed that the absorption spectra of fresh water glass in the region of $400-1400 \mathrm{~cm}^{-1}$ have the most pronounced band located at $1010 \mathrm{~cm}^{-1}$ with two shoulders at ca. 1120 and 890 $\mathrm{cm}^{-1}$ and less intense band at 615 and $455 \mathrm{~cm}^{-1}$. The most intense component at $1010 \mathrm{~cm}^{-1}$ lies in the middle bands $(1000$ and 1020 $\mathrm{cm}^{-1}$ ), attributed to Si-O stretching vibrations in $\mathrm{Q}^{1}$ and $\mathrm{Q}^{2}$ species, respectively [9]. Shifting of the main band towards higher wavenumbers of ca. $1100 \mathrm{~cm}^{-1}$ corresponds to an increase in the activity of $Q^{3}$ species, while lower wavenumbers of ca. $900 \mathrm{~cm}^{-1}$ are attributed to $\mathrm{Q}^{1}$ species. The shoulder at ca. $850 \mathrm{~cm}^{-1}$ is associated with the asymmetric vibrations of isolated $\mathrm{Q}^{0}$ species. The lower frequency envelope between $600-400 \mathrm{~cm}^{-1}$ is attributed to the rocking motion of $\mathrm{Si}-\mathrm{O}-\mathrm{Si}$ bridges connecting various $\mathrm{Q}^{\mathrm{n}}$ species [9]. According to the above, the main bands observed at $1010 \mathrm{~cm}^{-1}$ and $890 \mathrm{~cm}^{-1}$ indicate the presence of $Q^{1}$ and $Q^{2}$ species as a main silicate network group in fresh water glass of a 2.5 module [8].

In the second frequency range $\left(1400-4000 \mathrm{~cm}^{-1}\right)$, the characteristic strong adsorption bands with maximum at $3440 \mathrm{~cm}^{-}$ 1 , and narrow at $1647 \mathrm{~cm}^{-1}$ are observed. In addition, there is a small shoulder at $2280 \mathrm{~cm}^{-1}$. The bands of ca. $3440 \mathrm{~cm}^{-1}$ and 1640 $\mathrm{cm}^{-1}$ are attributed to the constitutional water molecules and $\mathrm{OH}-$ bending and stretching modes. The band within the range of 2400 - $2100 \mathrm{~cm}^{-1}$ corresponds to the vibrations of hydrogen bridges between $\mathrm{Si}(\mathrm{OH})_{4}$ and the silicate lattice.

After $24 \mathrm{~h}$ hardening, small changes and shifting of several bands in the absorption spectrum of water glass are observed. The wavenumber corresponds to the silicate network group vibrations, the main band at $1010 \mathrm{~cm}^{-1}$ is shifted to $1004 \mathrm{~cm}^{-1}$.

The bands related to vibrations of the molecules of water and $\mathrm{OH}$ group at $3440 \mathrm{~cm}^{-1}$ and $1640 \mathrm{~cm}^{-1}$ are shifted to $3352 \mathrm{~cm}^{-1}$ and $1658 \mathrm{~cm}^{-1}$ (unbound water). In addition, there is a band $\left(1435 \mathrm{~cm}^{-}\right.$ $\left.{ }^{1}\right)$ corresponding to the asymmetric stretching vibrations of $\mathrm{O}-\mathrm{C}-\mathrm{O}$ bonds [10]. These changes indicate binding of the carbon dioxide (from air) in accordance with the classic, total reaction:

$$
\begin{gathered}
\mathrm{xNa}_{2} \mathrm{O} \cdot \mathrm{ySiO} \mathrm{SH}_{2} \cdot \mathrm{zH}_{2} \mathrm{O}+\mathrm{CO}_{2} \longrightarrow \mathrm{Na}_{2} \mathrm{CO}_{3}+ \\
+(\mathrm{x}-1) \mathrm{Na}_{2} \mathrm{O} \cdot \mathrm{ySiO}_{2} \cdot \mathrm{zH}_{2} \mathrm{O}
\end{gathered}
$$

This reaction is generally accepted as a reaction valid in the water glass hardening process with $\mathrm{CO}_{2}$.

Figure 3 shows the effect of adding $5 \mathrm{wt} . \%$ of $\mathrm{MgO}$ in ethanol on the structure of fresh water glass. A small shift of some bands in the spectra of the examined samples, both fresh and hardened, is noticeable.

A significant shift of the band is observed to occur in the range of stretching vibrations of the $\mathrm{OH}$ groups (from 3420 to $\left.3440 \mathrm{~cm}^{-1}\right)$. A significant change is also noted in the intensity of this band due to the action of a modifier. The main band corresponding to asymmetric stretching vibrations of Si-O lying at the wavenumber of $1010 \mathrm{~cm}^{-1}$ in the spectrum of water glass is slightly shifting to the value of $1013 \mathrm{~cm}^{-1}$ due to the introduction of $\mathrm{MgO}$ nanoparticles in ethanol. Small shift towards lower wavenumbers is also observed in the band of $891 \mathrm{~cm}^{-1}\left(885 \mathrm{~cm}^{-1}\right)$, which can be the result of an increase in asymmetric vibrations of isolated $\mathrm{Q}^{0}$ species [11]. Similarly, the band appearing at $615 \mathrm{~cm}^{-1}$ is shifted to $607 \mathrm{~cm}^{-1}$, which can indicate a tendency to the reduction of ions in the system, too [12].

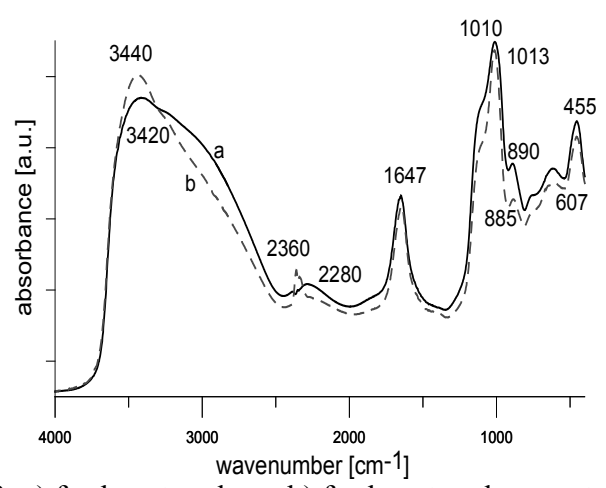

Fig. 3. a) fresh water glass b) fresh water glass containing $5 \mathrm{wt} . \%$ of $\mathrm{MgO}$ in ethanol

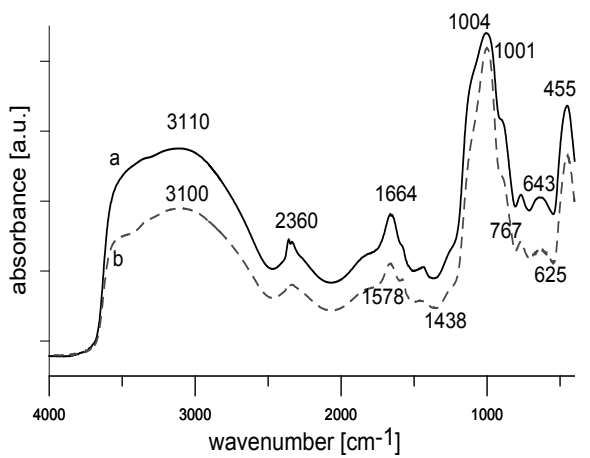

Fig. 4. a) water glass after $24 \mathrm{~h} \mathrm{~b}$ ) water glass with the addition of $5 \mathrm{wt} . \%$ of $\mathrm{MgO}$ in ethanol after $24 \mathrm{~h}$

The process of modified water glass hardening causes small shifts of bands associated with the $\mathrm{OH}$ groups and Si-O. There are also bands associated with carbonate groups in the water glass both unmodified and modified. On the other hand, important differences appear in the intensity of the spectra. In the case of the modified water glass spectrum, far lower intensity is shown throughout the whole range of wavenumbers, thus indicating an increased rate of the modified water glass hardening.

Figures 5 and 6 show spectra of the water glass modified with nanoparticles of $\mathrm{MgO}$ introduced in a propanol solvent.

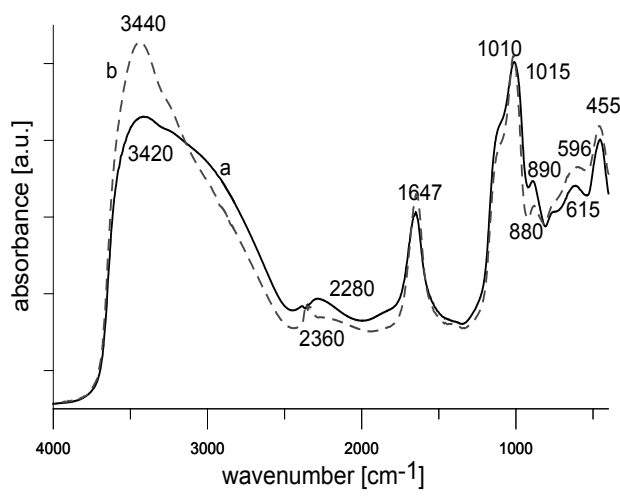

Fig. 5. a) fresh water glass b) fresh water glass with the addition of $5 \mathrm{wt} . \%$ of $\mathrm{MgO}$ in propanol 


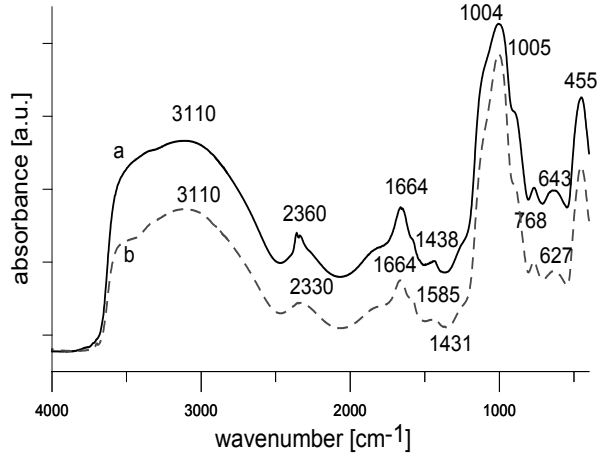

Fig. 6. a) water glass after $24 \mathrm{~h} \mathrm{~b}$ ) water glass with the addition of $5 \mathrm{wt} . \%$ of $\mathrm{MgO}$ in propanol after $24 \mathrm{~h}$

The $\mathrm{MgO}$ nanoparticles (5 wt.\%) introduced in propanol to fresh water glass (Fig. 5) show stronger effect on changes in the water glass structure than the same nanoparticles introduced in ethanol. The most significant change is the change in the intensity of the $\mathrm{OH}$ band $\left(3340 \mathrm{~cm}^{-1}\right)$ compared with that of the main band of Si-O $\left(1010 \mathrm{~cm}^{-1}\right)$. This type of change indicates an increase in the number of $\mathrm{OH}$ groups due to the introduction of $\mathrm{MgO}$ nanoparticles suspended in propanol.

Shifting the position of wavenumbers for the modified water glass $\left(890\right.$ to $880 \mathrm{~cm}^{-1}$ and 615 to $\left.596 \mathrm{~cm}^{-1}\right)$ indicates that $\mathrm{Mg}^{2+}$ ions are getting incorporated into the silicate network $[13,14]$. The hardening process is much faster with the addition of modifier ( $\mathrm{MgO}$ nanoparticles), no matter if in ethanol or propanol, as indicated by the spectrum intensity decreasing within the entire range of vibrations.

In the spectrum of the hardened water glass modified with $\mathrm{MgO}$ nanoparticles in either ethanol or propanol, the appearance of a band in the range of approximately $700 \mathrm{~cm}^{-1}$ confirms the participation of $\mathrm{Mg}^{2+}$ ions in the water glass cross-linking process [15]

\section{Conclusions}

Studies on the modification of water glass with colloidal solutions of $\mathrm{MgO}$ nanoparticles in ethanol and propanol showed the influence of magnesium nanoparticles on the hardening process of water glass through a reaction of this glass with $\mathrm{CO}_{2}$ and $\mathrm{MgO}$.

This confirms the characteristics of the spectra after $24 \mathrm{~h}$, i.e. the appearance of new bands in the region of carbonates (at about $1400 \mathrm{~cm}^{-1}$ and $700 \mathrm{~cm}^{-1}$ ).

Moreover, the presence of $\mathrm{MgO}$ nanoparticles significantly accelerates the hardening process. This is proved by a significant decrease in the intensity of the individual bands of a spectrum of the modified water glass.

\section{Acknowledgements}

The study was performed under the project No. N N508 475538

\section{References}

[1] Kuckui, P. (1990). Nowe kierunki rozwoju mas ze szkłem wodnym oraz elektrolitycznych metod mokrej regeneracji. Tłumaczenie artykułu zamieszczone w Przegladzie Odlewnictwa 6/90, 195-200.

[2] Stypuła, B. Banaś J., Habdank-Wojewódzki T., Krawiec H. \& Starowicz M.. PATENT: P-369 320 "Sposób otrzymywania mikro- i nanocząstek tlenków metali", report: 28.07.2004, grant: 07.10.2009.

[3] Avella, M., Bondioli, F., Cannillo, V., Errico, M.E., Ferrari, A.M., Focher, B., Malinconico, M., Manfredini, T. \& Montorsi, M. (2004). Preparation, characterisation and computational study of poly( $\varepsilon$-caprolactone) based nanocomposites. Materials Science and Technology vol.20 1340 - 1344. DOI:10.1179/0267 08304225022278.

[4] Kacperski, M. (2004). Wstępne badania nad wpływem rodzaju modyfikatora na właściwości nanokompozytów epoksydowych. Kompozyty nr 4 vol 9, 28-32.

[5] Wang, H., Bai, Y., Liu, S., Wu, J., Wong, C.P. (2002). Acta Materialia 50, 4369-4377 DOI: $10.1016 / \mathrm{S} 1359$ 6454(02)00275-6.

[6] Ji-na, W., Zi-tian, F., Hua-feng, W., Dong, X. \& Huang, N. (2007). An improved sodium silicate binder modified by ultra-fine powder materials. Chiuna Foundry vol.4.No.1, 2630 DOI: 1672-6421(2007)01-026-05.

[7] Zhu, Ch. (2007). Recent advances in waterglass sand technologies. China Foundry vol. 4. No.1, 13-17 DOI: 1672-6421(2007)01-013-05.

[8] Bobrowski, A., Hutera, B. Stypuła, B., Kmita, A., Drożyński, D., \& Starowicz, M. (2012). FTIR spectroscopy of water glass - the binder moulding modified by zno nanoparticles. Metalurgija, vol.51, No.4, 477-480.

[9] Roggendorf, H., Grond, W. \& Hurbanic, M. (1996). Glass Sci. Technol. 69 7, 216-230,

[10] Argawal, A. \& Tomozawa, M. (1997): Journal of NonCrystalline Solids 209, 166-174.

[11] Yuan, M., Lu J, Kong, G. \& Cheb C. (2011), Surface \& Coatings Technology 205, 4466-4470.

[12] Liu, H.S. (1997). Materials Chemistry and Physics 50, 1-10.

[13] Ma, J., Chen, C.Z., Wang, D.G. \& Shi, J.Z. (2012).Textural and structural studies of sol-gel derived $\mathrm{SiO} 2-\mathrm{CaO}-\mathrm{P} 2 \mathrm{O} 5$ $\mathrm{MgO}$ glasses by substitution of $\mathrm{MgO}$ for $\mathrm{CaO}$, Materials Science and Engineering C 30, 886-890 DOI: 10.1016/j.jnoncrysol.2007.07.076.

[14] Watts, S.J., Hill, R.G., O’Donnel, M.D. \& Law, R.V. (2012). Influence of magnesia on the structure and properties of bioactive glasses : Jurnal of Non-Crystalline Solids 356, 517-524 DOI:10.1016/j.jnoncrysol.2009.04.074.

[15] Silva, A.M.B., Queiroz, C.M, Agathopoulos, S., Correia, R.N, Fernandes, M.H.V. \& Olivera J.M. (2011). Structure of $\mathrm{SiO}_{2}-\mathrm{MgO}-\mathrm{Na}_{2} \mathrm{O}$ glasses by FTIR, Raman nad ${ }^{29} \mathrm{Si}$ MAS NMR, Journal of Molecular Structure $986,61-21$ : DOI: 10.10016/j.molstruc.2010.11.023. 